\title{
HUBUNGAN ANTARA EFIKASI DIRI DAN DUKUNGAN SOSIAL KELUARGA DENGAN MEKANISME KOPING KLIEN GAGAL GINJAL KRONIK YANG MENJALANI HEMODIALISA
}

\author{
Suwanti $^{1}$, Yetty $^{2}$, Faridah Aini ${ }^{1}$ \\ ${ }^{1}$ Fakultas Keperawatan, Universitas Ngudi Waluyo \\ ${ }^{2}$ Perawat RSUD Ambarawa \\ nick_farida@yahoo.co.id
}

\begin{abstract}
ABSTRAK
Hemodialisis pada klien Gagal Ginjal Kronik menyebabkan perubahan dalam hidup yang dapat membuat stres dan membutuhkan koping adaptif dalam mengatasinya.Kemampuan koping terhadap masalah yang dihadapi dapat dipengaruhi efikasi diri dan dukungan sosial keluarga. Individu yang memiliki efikasi diri tinggi dan dukungan sosial keluarga yang baik cenderung melakukan mekanisme koping yang adaptif. Tujuan. Tujuan penelitian ini untuk mengetahui hubungan antara efikasi diridan dukungan sosial keluarga dengan mekanisme koping klien Gagal Ginjal Kronik yang menjalani hemodialisa di RSUD Ambarawa. Design penelitian korelasional pendekatan cross sectional. Populasinya penderita Gagal Ginjal Kronik yang menjalani Hemodialisa sejumlah 48 pasien. Pengambilan sampel dengan total sampling. Sampel sebanyak 34 orang. Pengumpulan data dilakukan dengan menggunakan kuesioner. Analisis data dengan program SPSS, uji statistik Fischer's Exact Test. Terdapat hubungan yang signifikan antara efikasi diri dengan mekanisme koping dengan $\mathrm{p}$ value sebesar 0,039 $(\alpha=0,05)$ dan terdapat hubungan yang signifikan antara dukungan sosial keluarga dengan mekanisme koping dengan $\mathrm{p}$ value sebesar $0,004(\alpha=0,05)$. Terdapat hubungan yang signifikan antara efikasi diri dan dukungan sosial keluarga dengan mekanisme koping nilai signifikansi 0,039 dan 0,004 pada $\alpha 0,05$.
\end{abstract}

Kata Kunci: Efikasi diri, dukungan sosial keluarga, mekanisme koping

\section{THE CORRELATION BETWEEN SELF-EFFICACY AND FAMILIES SOCIAL SUPPORT WITH COPING MECHANISMS CLIENTS CHRONIC RENAL FAILURE UNDERGOING HEMODIALYSIS}

\begin{abstract}
Hemodialysis in chronic renal failure client causes changes in life that can create stress and need coping to solve. Coping mechanism with the problems encountered could be affected by self-efficacy and family social support. Client with high self efficacy and good family social support use adaptif coping mechanism. Purpose. The purpose of this study is to determine the correlation between selfefficacy and families social support with coping mechanisms clients Chronic Renal Failure undergoing hemodialysis at Ambarawa general hospital. This research used correlational design with cross sectional approach. The population were patients with Chronic Renal Failure who did Hemodialysis at RSUD Ambarawa as much as 48 patients. The sampling technique used total sampling. The samples study were patients with Chronic Renal Failure who did Hemodialysis that reguire inclusion and exclusion criteria as many as 34 people. The data collection was done by using a questionnaire. Data analysis was performed with SPSS by using Fischer's Exact. There was significant correlation between self efficacy with coping mechanism ( $p$ value $<0,005$ ). And there was significant correlation between family social support with coping mechanism ( $p$ value $<0,005$ ). There is a significant correlation between self-efficacy and social support of families with coping mechanisms with significant value of 0.039 and 0.004 at $\alpha=0.05$.
\end{abstract}

Keywords: Self efficacy, family social support, coping mechanisms 


\section{PENDAHULUAN}

Chronic Kidney Disease (CKD) atau Gagal Ginjal Kronik (GGK) adalah kerusakan ginjal yang menyebabkan ginjal tidak dapat membuang racun dan produk sisa dari darah, ditandai adanya protein dalam urin serta penurunan laju filtrasi glomerulus, berlangsung lebih dari 3 bulan. Berbagai macam penyakit dapat menyebabkan penyakit ginjal kronik, masing-masing memiliki patofisiologi sendirisendiri, namun secara umum gejala yang ditimbulkan seperti gangguan cairan dan elektrolit (Black \& Hawks, 2014).

Reaksi yang muncul pada klien dengan penyakit kronik seperti Gagal Ginjal Kronik meliputi aspek fisik, aspek psikologi aspek sosial dan ekonomi. Aspek fisik bisa timbul mual,muntah, sakitkepala danhipertensi. Aspek psikologis seperti shock, tidak percaya, depresi, marah. Masalah sosial menyebabkan perubahan peran, mengubah citra tubuh dan mengganggu gaya hidup yang ada. Aspek ekonomi seperti kehilangan pekerjaan, biaya untuk tindakan hemodialisa(Smeltzer \& Bare, 2007). Kondisi ini tentunya dapat membuat pasien stres dan membutuhkan mekanisme koping untuk mengatasinya.

Mekanisme koping individu dalam menangani situasi yang mengandung tekanan ditentukan oleh faktor individu dan faktor interpersonal. Faktor individu seperti usia, pertumbuhan, perkembangan, faktor genetik, kesehatan fisik, hardiness, resilience, spiritualitas dan efikasi diri. Faktor interpersonal meliputi perasaan memiliki, jaringan social dan dukungan sosial keluarga (Videback S,2008). Mekanisme koping yang ditunjukkan oleh individu bisa adaptif bisa juga maladaptif.

Mekanisme koping adaptif ditunjukan dengan kemampuan memecahkan masalah dan mampu bercerita dengan orang lain. Koping maladaptif seperti makan berlebihan, tidak mau berbicara, marah-marah. Individu dengan mekanisme koping positif biasanya memiliki keyakinan diri yang tinggi untuk memecahkan masalah. Keyakinan diri yang tinggi menjadi sumber daya psikologis yang sangat penting sehingga mengerakan individu untuk mengatasi permasalahan yang dihadapi (Lestari, 2015). Keyakinan diri merupakan keyakinan individu akan kemampuannya dalam melakukan perilaku yang mendukung perawatan dirinya.Hal ini penting dalam menentukan status kesehatan dan bagaimana berespon terhadap masalah yang dihadapi. Individu yang memiliki keyakinan diri tinggi tentunya akan mampu berespon dan beradaptasi dengan menggunakan mekanisme koping yang adaptif.

Selain faktor individu mekanisme koping individu juga dipengaruhi oleh faktor interpersonal berupa dukungan sosial keluarga. Status sehat sakit para anggota keluarga dan keluarga saling mempengaruhi satu sama lain. Suatu penyakit dalam keluarga mempengaruhi jalannya suatu penyakit dan status kesehatan anggota keluarga (Friedmann, 2013). Bentuk dukungan sosial keluarga yaitu dukungan emosional, dukungan penghargaan (penilaian), dukungan instrumental dan dukungan informatif. Tujuan penelitian ini adalah untuk mengetahui hubungan antara Efikasi diri (self efficacy) dan dukungan sosial keluarga dengan mekanisme koping klien Gagal Ginjal Kronik yang menjalani hemodialisa di RSUD Ambarawa

\section{METODE}

Jenis penelitian ini adalah kuantitatif non experimental design corelasional dengan pendekatan cross sectional. Penelitian ini dilaksanakan Tanggal 6-8 Agustus 2016 di ruang Hemodialisa RSUD Ambarawa. Populasi dalam penelitian ini adalah seluruh pasien gagal ginjal kronik yang menjalani hemodialisa di RSUD Ambarawa sejumlah 48 pasien. Tehnik sampling yang digunakan adalahtotal sampling. Sampel yang digunakan sejumlah 34 responden yang memenuhi kriteria pasien gagal ginjal kronis yang menjalani hemodialisa, lama menjalani hemodialisa $\leq 2$ tahun, bersedia menjadi responden dan menggunakan jaminan kesehatan.Alat pengumpulan data adalah dengan menggunakan kuesioner. Bagian pertama untuk mengetahui karakteristik responden, bagian kedua untuk mengetahui Efikasi diri (self efficacy), bagian ketiga untuk mengetahui dukungan sosial keluarga, bagian ke empat untuk mengetahui mekanisme koping. Variabel mekanisme koping akan diukur dengan menggunakan Jolowiec Coping Scale yang sudah diadaptasi ke dalam Bahasa Indonesia.

Pengumpulan data dilakukan melalui tahaptahap sebagai berikut; menyelesaikan perijinan, memilih dan melatih enumerator pengambil data; Penelitimemilihdua orang perawat yang bekerja di Ruang Hemodialisa RSUD Ambarawa, peneliti memberikan 
penjelasan dan persamaan persepsi tentang proses penelitian yang dilakukan.Asisten peneliti bertugas untuk membantu peneliti dalam memilih responden yang sesuai dengan kriteria inklusi dan ekslusi, menjelaskan tujuan dan meminta responden menandatangani lembar persetujuan serta mengumpulkan kuesioner yang telah diisi. Pengumpulan data dari responden dikumpulkan melalui beberapa tahapan, yaitu: Satu jam setelah responden yang memenuhi kriteria selesai melaksanakan Hemodialisa, responden diminta untuk mengisi kuesioner.

Sebelum mengisi kuesioner penelitian, peneliti menjelaskan mengenai tujuan penelitian, manfaat penelitian, penelitian yang dilakukan tidak menimbulkan dampak buruk dan cara pengisian kuesioner kepada responden itu sendiri.Setelah responden memahami mengenai informasi penelitian dan bersedia menjadi responden, responden diminta untuk menandatangani lembar persetujuan.Setelah respondenmenandatanganilembar persetujuan, responden diminta mengisi kuesioner. Pengisian kuesioner dilakukan setelah pasien menjalani Hemodialisa. Saat pengisian, peneliti berada di dekat responden karena bila ada pertanyaan kurang jelas dari responden mengenai pertanyaan kuesioner peneliti dapat segera memberi penjelasan. Pada saat pengisian kuesioner dari 34 responden tidak ada yang mengalami kelelahan, sakit kepala, pusing, muntah atau terjadi komplikasi yang sering setelah hemodialisa. Kuesioner yang berjumlah 34 oleh peneliti dan asisten peneliti diperiksa kembali kelengkapan jawaban dari responden. Semua kuesioner terisi dengan lengkap dan jelas. Peneliti dan asistenmengumpulkan semua kuesioner dari responden. Kuesioner yang terkumpul disimpan dalam map yang tertutup sehingga tidak bisa dibaca oleh orang lain yang tidak berkepentingan. Data siap diolah dan dianalisa.

Analisis univariat berupa distribusi frekuensi untuk variabel efikasi diri, dukungan sosial keluarga dan mekanisme koping. Dan analisis bivariat untuk melihat hubungan antara variabel independen yaitu keyakinan diri dan dukungan keluarga dengan variabel dependen yaitu mekanisme koping.Analisis hubungan dilakukan dengan ujiFischer's Exact.

\section{HASIL}

Hasil penelitian dapat dilihat pada grafik berikut.

Grafik I.

Distribusi Karakteristik Responden Klien Gagal Ginjal Kronik Yang Menjalani Hemodialisa (n=34)
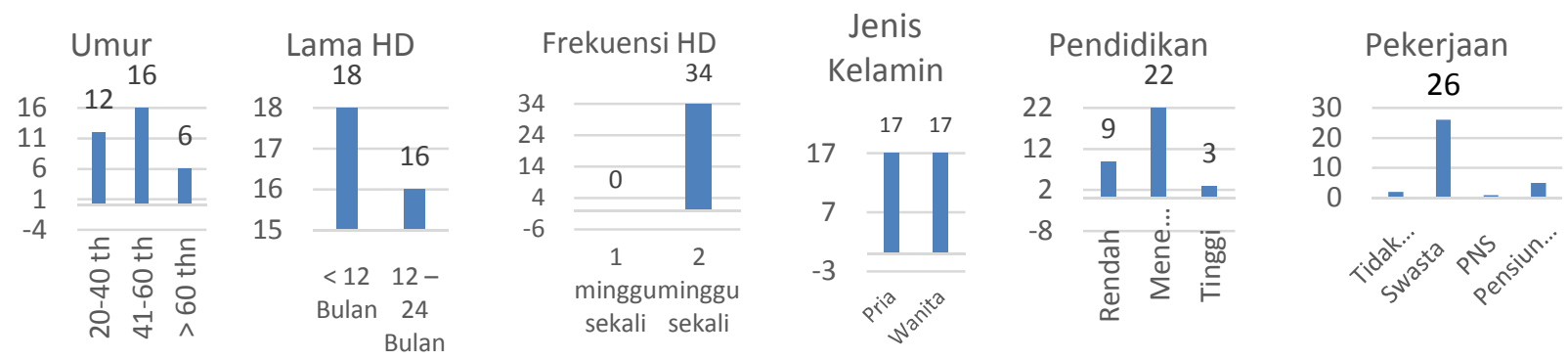

Grafik 2.

Distribusi Efikasi Diri Klien Gagal Ginjal Kronik Yang Menjalani Hemodialisa Di RSUD Ambarawa $(\mathrm{n}=34)$

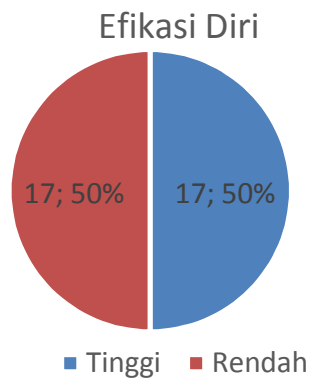


Grafik 3.

Dukungan Sosial Keluarga Klien Gagal Ginjal Kronik Yang Menjalani Hemodialisa (n=34)

Dukungan Sosial Keluarga

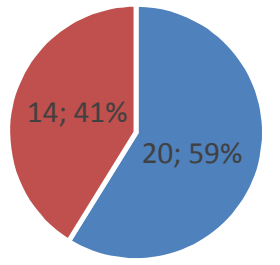

- Baik - Tidak baik

Grafik 4.

Distribusi Mekanisme Koping Klien Gagal Ginjal Kronik Yang Menjalani Hemodialisa (n=34)

\section{MEKANISME KOPING}

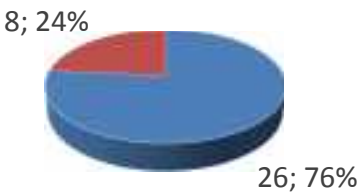

- Adaptif

Berdasarkan Grafik 1 diketahui karakteristik responden: $47.1 \%$ berumur 41-60 tahun, $52.9 \%$ menjalani HD < 12 bulan, frekuensi HD semuanya $2 \mathrm{x}$ dalam seminggu, jenis kelamin antara pria dan wanita sama, $38,2 \%$ berpendidikan menengah, $64.8 \%$, bekerja di sektor swasta $76.46 \%$. Grafik 2 menunjukkan bahwa dari 34 responden, efikasi diri responden kategori tinggi dan rendah sama

\section{- Mal Adaptif}

yaitu sebanyak 17 orang (50\%). Grafik 3 menunjukkan bahwa dari 34 responden, hampir dua pertiga responden mendapatkan dukungan sosial keluarga yang baik (58.5\%). Grafik 4 menunjukkan bahwa dari 34 responden, sebagian besar responden memiliki mekanisme koping yang adaptif sebanyak 26 responden $(76.5 \%)$, dan sisanya memiliki mekanisme koping yang maladaptif (23.5\%).

Tabel 1.

Hubungan Antara Efikasi Diridengan Mekanisme KopingKlien Gagal Ginjal Kronik Yang Menjalani Hemodialisa $(\mathrm{n}=34)$

\begin{tabular}{lccccccc}
\hline \multirow{2}{*}{ Efikasi Diri } & \multicolumn{4}{c}{ Mekanisme Koping } & \multicolumn{2}{c}{ Total } & \multirow{2}{*}{ P value } \\
\cline { 2 - 5 } & \multicolumn{1}{c}{ Maladaptif } & \multicolumn{3}{c}{ Adaptif } & & $\%$ & \\
\cline { 2 - 6 } & $\Sigma$ & $\%$ & $\sum$ & $\%$ & & $\%$ & \\
\hline Rendah & 7 & 41.2 & 10 & 58.8 & 17 & 100 & \\
Tinggi & 1 & 5.8 & 16 & 94.1 & 17 & 100 & 0,039 \\
\hline
\end{tabular}

Tabel 2.

Hubungan Antara Dukungan Sosial Keluargadengan Mekanisme KopingKlien Gagal Ginjal Kronik Yang Menjalani Hemodialisa $(n=34)$

\begin{tabular}{|c|c|c|c|c|c|c|c|}
\hline \multirow{3}{*}{$\begin{array}{c}\text { Dukungan Sosial } \\
\text { Keluarga }\end{array}$} & \multicolumn{4}{|c|}{ Mekanisme Koping } & \multicolumn{2}{|c|}{ Total } & \multirow{3}{*}{$P$ value } \\
\hline & \multicolumn{2}{|c|}{ Maladaptif } & \multicolumn{2}{|c|}{ Adaptif } & \multirow[b]{2}{*}{$\sum$} & \multirow[b]{2}{*}{$\%$} & \\
\hline & $\sum$ & $\%$ & $\sum$ & $\%$ & & & \\
\hline Tidak Baik & 7 & 50 & 7 & 50 & 14 & 100 & \\
\hline Baik & 1 & 5 & 19 & 95 & 20 & 100 & 0,004 \\
\hline
\end{tabular}

Berdasarkan tabel 1 menunjukkan bahwa mekanisme koping yang adaptif (29.4\%) dan sebanyak 10 responden yang memiliki efikasi hanya 1 responden yang memiliki efikasi diri diri rendah tetapi responden memiliki tinggi tetapi memiliki mekanisme koping yang 
mal adaptif (2.9\%). Berdasarkan hasil uji statistik dengan Fisher's Exact dengan tingkat signifikasi $95 \%(\alpha=0,05)$ ada hubungan yang signifikan antara efikasi diridengan mekanisme koping dengan $\mathrm{p}$ value sebesar 0,039 ( $\alpha=$ $0,05)$.

Tabel 2 menujukkan hasil bahwa ada sebanyak 7 orang yang memiliki dukungan sosial keluarga yang tidak baik tetapi memiliki mekanisme koping yang adaptif (20.6\%) dan hanya ada 1 orang responden yang mendapatkan dukungan sosial keluarga yang baik tetapi memilii mekanisme koping mal adaptif (2.9\%). Berdasarkan hasil uji statistik dengan Fisher's Exact dengan tingkat signifikasi $95 \%(\alpha=0,05)$ ada hubungan yang signifikan antara dukungan sosial keluargadengan mekanismekoping.

\section{PEMBAHASAN}

\section{Gambaran efikasi diri Klien Gagal Ginjal Kronik Yang Menjalani Hemodialisa}

Hasil penelitian menunjukkan jumlah responden yang memiliki efikasi diritinggidan rendah sama yaitu sebanyak 50\%,penelitian lain mendapatkan hasil yang berbeda dimana $77,8 \%$ pasien gagal ginjal yang menjalani hemodialisa di Rumah Sakit Al-Islam Bandung cenderung memiliki efikasi diriyang tinggi. Sedangkan $22,2 \%$ pasien gagal ginjal yang menjalani hemodialisa lainnya memiliki efikasi diriyang rendah. (Septiady, Suhana, 2014).Berdasarkan jawaban responden hampir sebagian besar responden menjawab yakin untuk setiap item pertanyaan, mulai dari pertanyaan 1 sampai dengan pertanyaan 9 . Responden yang menjawab sangat yakin atau tidak yakin hanya sebagian kecil saja.

Berdasarkan kelompok umur, responden yang memiliki efikasi diri tinggi berada pada kelompok umur 40-60 tahun, menurut peneliti sesuai dengan tahap perkembangan manusia pada kelompok ini individu sudah berada pada tahap dewasa akhir dimana kemampuan untuk mengendalikan emosi, berfikir dalam menghadapi masalah sudah matang. Berdasarkan pendidikan, responden yang memiliki efikasi diri rendah sebagian pada kelompok pendidikan rendah, menurut peneliti hal ini berhubungan dengan pengalaman, individu dengan pendidikanrendah tentunya akan memiliki pengalaman yang lebih sedikit dibanding dengan yang berpendidikan lebih tinggi. Faktor pengetahuan dan pengalaman inilah yang menyebabkan perbedaan dalam efikasi diri.

Berdasarkan pekerjaaan responden yang bekerja di sektor swasta yang paling banyak memiliki efikasi diri yang rendah, menurut peneliti hal ini dimungkinkan karena individu yang bekerja di sektor swasta sangat tergantung pada hasil kerjanya jika individu sakit maka kinerjanya akan menurun sehingga akan berdampak pada efikasi diri, menjadi kurang yakin dengan tindakan pengobatan yang dilakukan.Berdasarkan jenis kelamin responden berjenis kelamin pria paling banyak memiliki efikasi diri yang rendah, menurut peneliti hal ini dapat disebabkan karena sebagai seoarang kepala keluarga tentunya dituntut untuk lebih berperan dalam keluarga tetapi karena kondisinya saat ini yang sedang sakit sehingga menyebabkan individu kurang yakin akan tindakan pengobatan yang dilakukan saat ini. Berdasarkan frekuensi menjalani HD, responden yang melakukan HD kurang dari 1 tahun memiliki efikasi diri yang tinggi menurut peneliti hal ini dimungkinkan karena waktu menjalani HD yang belum terlalu lama sehingga individu belum merasa bosan dan yakin akan tindakan pengobatan yang sedang dijalankan dapat meningkatkan kesehatannya.

Banyaknya responden yang memiliki efikasi diritinggi menurut peneliti disebabkan karena faktor pengalaman orang lain, beberapa responden menyatakan bahwa pada saat sedang melakukan hemodialisa biasanya akan saling bercerita tentang pengalaman masingmasing pasien dalam menghadapi kondisinya, hal ini menyebabkan responden merasa yakin dapat mengatasi kondisi yang sedang dialaminya.Faktor lain adalah persuasi verbal. Persuasi verbal adalah cara lain untuk memperkuat keyakinanseseorang tentang efikasi diri. Hal ini dapat terwujud karena setiap perawat yang dinas di ruang hemodialisa sudah dibekali dengan pelatihan hemodialisa, sehingga memang perawat yang memiliki kompetensi yang dapat bekerja di ruangan hemodialisa. Setiap perawat selama melakukan perawatan pada klien hemodialisa akan memotifasi pasien agar tetap bisa melaksanakan aktifitas seperti biasanya, hal ini menimbulkan keyakinan diri dari pasien akan meningkat.

Efikasi diri adalah keyakinan seseorang akankeberhasilan dalam melakukan perawatan diri untuk mencapai hasil yang diinginkan. 
Seseorang dengan peningkatan persepsi dalam aktivitas perawatan diri akan lebih mudah berpartisipasi dalam aktivitas perawatan diri sehingga akan meningkatkan kepatuhan terhadap regimen terapeutik. Proses pembentukan efikasi diri dilakukan melalui proses kognitif, motivasional, afektif dan seleksi sepanjang kehidupan. Fungsi kognitif memungkinkan individu untuk memprediksi kejadian-kejadian sehari-hari yang akan berakibat pada masa depan. Individu akan meramalkan kejadian dan mengembangkan cara untuk mengontrol kejadian yang mempengaruhi hidupnya. Sebagian besar motivasi dihasilkan dari proses kognitif. Dengan motivasi kognitif seseorang memotivasi mereka sendiri dan memandu tindakan antisipasi mereka melalui pemikiran ke masa depan. Untuk mencapaikeberhasilan diperlukan keyakinan dan rasa optimis.

\section{Gambaran Dukungan Sosial KeluargaKlien Gagal Ginjal Kronik Yang Menjalani Hemodialisa}

Hasil penelitian menunjukkan sebagian besar respondenmendapatkan dukungan keluarga yang baik yaitu sebanyak $58.5 \%$. Penelitian lain mendapatkan hasil yang sama dimana $86 \%$ responden gagal ginjal yang menjalani hemodialisa di RSUP Dr Soeraji Tirtonegoro Klaten mendapatkan dukungan keluarga (Nekada, 2012). Penelitian lain yang dilakukan Arinta (2012) didapatkan hasil yang sama dimana sebagian besar responden mendapatkan dukungan sosial keluarga yang baik.

Berdasarkan kelompok umur, responden yang mendapat dukungan sosial keluarga baik berada pada kelompok umur 40-60 tahun, menurut peneliti hal ini dapat terjadi karena pada usia ini tahap perkembangan keluarga sudah berada pada tahap usia pertengahan dimana anak-anaknya sudah pada bekerja, kebutuhan ekonomi tidak terlalu banyak sehingga keluarga bisa memberikan dukungan sepenuhnya pada penderita gaga 1 ginjal yang menjalani hemodialisa. Berdasarkan pendidikan, responden yang memiliki dukungan sosial baik sebagian pada kelompok pendidikan menengah, menurut peneliti hal ini berhubungan dengan pengetahuan, sesorang yang cukup pengetahuannya akan berusaha mencari informasi berkaitan dengan penyakitnya sehingga bisa memberikan perawatan terbaik bagi penderita.
Berdasarkan pekerjaaan responden yang bekerja di sektor swasta, wiraswasta, pensiunan yang paling banyak memiliki dukungan keluarga yang baik, menurut peneliti hal ini dimungkinkan karena faktor ekonomi. Jenis pekerjaan tentunya akan berdampak pada seberapa penghasilan yang diperoleh, dengan penghasilan yang cukup atau lebih tentunya keluarga dapat memberikan dukungan yang lebih optimal. Berdasarkan jenis kelamin responden berjenis kelamin wanitayang paling banyak memiliki dukungan keluarga yang baik, menurut peneliti hal ini dapat disebabkan karena peran vital seorang ibu dalam keluarga, sehingga apabila ibu dalam keadaan yang tidak sehat maka seluruh keluarga akan berupaya memberikan dukungan yang terbaik baik penderita agar cepat sembuh dan dapat menjalankan peran seperti semula sebagai ibu didalam rumah tangga. Berdasarkan frekuensi menjalani HD, responden yang melakukan HD kurang dari 1 tahun memiliki dukungan sosial keluarga yang baik menurut peneliti hal ini dimungkinkan karena waktu menjalani HD yang belum terlalu lama sehingga keluarga belum merasa bosan dan masih tetap setia memberikan dukungan kepada penderita.

Dukungan sosial keluarga dalam penelitian ini meliputi dukungan informasional, dukungan emosional, dukungan penilaian dan dukungan instrumental.Dukungan informasi yang diberikan oleh keluarga pada penderita gagal ginjal kronik yang menjalani Hemodialisa meliputi aspek pemberian nasehat, saran, petunjuk serta pemberian informasi tentang pentingnya tindakan hemodialisa. Dukungan emosional diwujudkan melalui peran keluarga memberikan rasa empati, kepedulian, adanya kepercayaan, perhatian dan mendengarkan atau didengarkan terhadap orang yang bersangkutan.Dukungan penghargaan (penilaian) melalui bimbingan dengan memberikan umpan balik, membimbing dan membantu pemecahan masalah, memberikan penghargaan positif. Bentuk dukungan instrumental melalui penyediaan kebutuhan seperti obat, pengobatan, bentuk uang untuk biaya pengobatan, pemilihan fasilitas.

Berdasarkan jawaban responden dukungan sosial yang paling banyak diberikan oleh keluarga adalah dukungan instrumen. 85.5\% keluarga tidak pernah meminta anda bekerja ketika tidak sedang menjalani hemodialisa, $55.9 \%$ keluarga sering membelikan obat jika ada keluhan pada saat di rumah, 79.4 keluarga 
sering memberikan biaya untuk pengobatan ke pelayanan kesehatan, $85.3 \%$ keluarga sering memberi kesempatan untuk memilih fasilitas kesehatan untuk kontrol setiap bulan. Hal ini dimungkinkan karena sebagian besar biaya Hemodialisa ditanggung oleh BPJS, sehingga keluarga dapat menggunakan uang yang dimiliki untuk keperluan yang lainnya dalam mendukung pengobatan klien.Dukungan yang masih kurang adalah dukungan informasi. Hal ini dimungkinkan karena keluarga sendiri juga tidak paham mengenai program Hemodialisa karena sebagian besar responden juga berpendidikan rendah. Namun keluarga tetap menasehati untuk selalu patuh menjalani hemodialisa, menganjurkan untuk bertanya seputar hemodialisa yang sedang dijalani.

Banyaknya keluarga yang memberikan dukungan dengan baik kepada penderita gagal ginjal kronik yang menjalani Hemodialisa menunjukkan keluarga mampu memberikan dukungan kepada klien, keluarga dianggap sebagai satu kesatuan harus saling mengasihi dan memperhatikan. Friedman (2013) mengatakan bahwa keluarga menjadi pusat utama yang penting dan hanya keluargalah yang memperhatikan individu secara total dan memperhatikan setiap aspek-aspek kehidupannya.

Penelitian ini mendapatkan adanya responden yang tidak mendapatkan dukungan dengan baik sebanyak 14 responden (41.2\%). Menurut peneliti masih adanya keluarga yang tidak memberikan dukungan dengan baik disebabkan karena faktor sosial ekonomi, dimana pasangan hidup atau keluarga sibuk dengan urusannya dalam bekerja untuk memenuhi kebutuhan hidup sehingga keluarga memiliki waktu yang kurang atau lalai dalam memberikan dukungan kepada penderita gagal ginjal kronik yang menjalani Hemodialisa.

Dukungan dari keluarga merupakan unsur terpenting dalam membantu individu menyelesaikan masalah. Adanya dukungan membuatrasa percaya diri, penderita gagal ginjal kronik akan merasa senang dan tentram apabila mendapat perhatian dan dukungan dari keluarganya, karena dengan dukungan tersebut akan menimbulkan kepercayaan dirinya untuk menghadapi atau mengelola penyakitnya dengan lebih baik. Dukungan keluarga yang kurang dapat menurunkan motivasi penderita gagal ginjal kronik untuk melakukan perawatan kesehatan. Sedangkan dukungan yang baik akan meningkatkan motivasi penderita gagal ginjal kronik untuk melakukan perawatan kesehatan dalam hal melakukan hemodialisa secara teratur.Sumber dukunganpaling sering diberikan oleh pasangan hidup atau anak.

Hal ini selaras dengan Friedman, (2013) bahwa ada 4 bentuk dukungan sosial keluarga yaitu dukungan emosional, dukungan penghargaan, dukungan instrumental dan dukungan informasional. Dukungan emosional merujuk pada empati, kepedulian, adanya kepercayaan, perhatian dan mendengarkan atau didengarkan terhadap orang yang bersangkutan. Dukungan penilaian dalam bentuk bimbingan umpan balik, membimbing dan menengahi pemecahan masalah. Dukungan instrumental dalam bentuk uang, peralatan, waktu, modifikasi lingkungan maupun menolong. Dukungan informatif dalam bentuk nasehat, saran, petunjuk dan pemberian informasi.

\section{Gambaran Mekanisme KopingKlien Gagal} Ginjal Kronik Yang Menjalani Hemodialisa Hasil penelitian menunjukkan bahwa dari 34 responden, sebagian besar respondenmemiliki mekanisme koping yang adaptif sebanyak 26 responden $(76.5 \%)$, dan sisanya memiliki mekanisme koping yang maladaptif $(23.5 \%)$. Hasil penelitian lain didapatkan hasil sama dimana 71,4 \%responden memiliki koping yang adaptif(Asmarani, 2012).

Berdasarkan kelompok umur, responden yang memiliki mekanisme koping yang adaptif berada pada kelompok umur 40-60 tahun, menurut peneliti hal ini dapat terjadi karena pada usia ini individu lebih matang secara emosional, secara spiritual juga lebih bagus sehingga bisa sadar bahwa apa yang dialami sebagai suatu cobaan dan dengan sabar menerima sehingga kopingnya lebih adaptif. Responden juga menyatakan kalau hal yang dialami adalah cobaan dari sang kuasa, manusia hanya berusaha sedang hasilnya diserahkan kepada yang kuasa maka lebih tenang dan merasa lebih baik dalam menjalani Hemodialisa. Berdasarkan pendidikan, responden yang menggunakan koping yang adaptif sebagian pada kelompok pendidikan menengah, menurut peneliti hal ini berhubungan dengan pengalaman sesorang dalam menghadapi masalah, orang yang berpengalaman akan lebih memiliki banyak alternatif tindakan ketika menghadapi suatu masalah. 
Berdasarkan pekerjaan responden yang bekerja di sektor swasta, yang paling banyak menggunakan koping yang adaptif, menurut peneliti hal ini dimungkinkan karena faktor kesibukan. Orang yang bekerja tentunya pikiran tidak terlalu fokus pada penyakitnya sehingga lebih mampu menggunakan koping yang adaptif, atau tetap aktif bekerja untuk mendapatkan biaya pengobatan.Berdasarkan jenis kelamin responden berjenis kelamin wanita yang paling banyak memiliki mekanisme koping yang adaptif, menurut peneliti hal ini dapat disebabkan faktor jenis kelamin berhubungan dengan perilaku seseorang. Perilaku yang dilakukan laki-laki biasanya lebih dominan, agresif, bersikap bermusuhan dan destruktif. Sedangkan perempuan cenderung bersikap terbuka, berserah diri dan konstruktif.

Berdasarkan frekuensi menjalani HD, responden yang melakukan HD kurang dari 1 tahun memiliki mekanisme koping yang adaptif menurut peneliti hal ini dimungkinkan karena dampak yang ditimbulkan dari Hemodialisa dapat meningkatkan status kesehatan sehingga secara fisik lebih baik maka mekanisme kopingnya lebih baik atau adaptif. Menurut Lestari (2015) koping stress merupakan perilaku yang ditujukan seseoarang untuk mengatasi stres yang dialami dengan tujuan mencegah dampak negatif yang muncul.

Berdasarkan data penelitian koping adaptif yang digunakan seperti selalu mengajak orang lain untuk menyelesaikan masalah atau mengatasi situasi dilakukan oleh 20.6\% responden, $20.6 \%$ responden mengatakan tetap menjalani pengobatan meskipun tidak yakin akan berhasil, $35.3 \%$ responden selalu membicarakan masalah dengan orang yang pernah mengalami situasi yang sama, $35.3 \%$ responden selalu mencoba melihat masalah secara objektif dan melihat dari semua sisi, $29.4 \%$ responden selalu mencoba menemukan arti atau hikmah dari situasi yang dialami dan $70.6 \%$ responden selalu berdoa, beribadah danberserah diri pada Tuhan YME.

Proses mekanisme koping bukan hanya satu kejadian karena koping melibatkan interaksi antara lingkungan dan proses tersebut dilihat sebagai proses yang dinamis. Stres yang muncul pada individu akan membuat dirinya melakukan koping. Koping merupakan tindakan mengubah kognitif secara konstan dan usaha tingkah laku untuk mengatasi tuntutan internal atau eksternal yang dinilai membebani atau melebihi kemampuan yang dimiliki individu (Nasir, 2011).

Penyakit gagal ginjal merupakan penyakit kronik dan salah satu terapinya adalah hemodialisis yang akan menyebabkan perubahan peran, citra tubuh, mengancam identitas dan mengubah gaya hidup yang ada. Perubahan-perubahan yang terjadi dan adanya ancaman dalam diri individu membuat seseorang berusahauntuk mengatasinya dan usaha yang dilakukan oleh individu dalam menghadapimasalah disebut mekanisme koping. Banyaknya responden yang memiliki mekanisme koping yang adaptif menurut peneliti dimungkinkan karenaklien sudah mengalami dialisis berulang kali sehingga sudah menjadi pola dalam kehidupannya. Salah satu pengggunaan mekanisme koping tergantung dari pengalaman masa lalu yang pernah dialami klien (Mutoharoh,2009).

\section{Hubungan Antara Efikasi Diri dengan Mekanisme KopingKlien Gagal Ginjal Kronik Yang Menjalani Hemodialisa}

Hasil penelitian menunjukkan bahwa ada hubungan yang signifikan antara efikasi diri dengan mekanisme koping penderita Gagal Ginjal Kronik yang menjalani Hemodialisa. Hasil ini sesuai dengan penelitian yang dilakukan oleh Mutoharoh(2009), dimana didapatkan hasil adanya hubungan antara harapan akan self-efficacy klien GGK yang menjalani terapi hemodialisis dengan mekanisme koping.

Berdasarkan kelompok umur responden yang memiliki efikasi diri berada dalam usia 40-60 tahun dan pada kelompok ini sebagian besar juga memiliki mekanisme koping yang adaptif. Menurut peneliti hal ini terjadi karena pada usia ini individu akan mencapai titik kematangan secara emosional jadi lebih mampu mengontrol stress dan menggunakan mekanisme koping yang adaptif seperti mengajak orang lain untuk menyelesaikan masalah atau mengatasi situasi, tetap menjalani pengobatan, meskipun tidak yakin akan berhasil, membicarakan masalah dengan orang yang pernah mengalami situasi yang sama.

Berdasarkan jenis kelamin responden yang memiliki efikasi diri tinggi adalah berjenis kelamin perempuan dan pada kelompok ini juga memiliki mekanisme koping yang adaptif. 
Hasil ini didukung oleh penelitian Rofiqoh dkk (2013) dimana didapatkan hasil pada pasien Gagal Ginjal Kronik perempuan lebih kearah adaptif seperti, sharing dengan orang lain dan mencari solusi.Berdasarkan lama menjalani HD responden yang memiliki efikasi diri tinggi pada kelompok responden yang menjalani HD $<1$ tahun, dan pada kelompok ini juga memiliki mekanisme koping yang adaptif. Hasil ini didukung penelitian Asmarani (2012) dimana didapatkan hasil Mekanisme koping adaptif paling tinggi digunakan pada pasien GGK yang telah lama sakit 1-3 tahun. Pasien GGK dengan hemodialisa jangka panjang, mereka telah berada pada tahap resolusi sehingga sudah terbiasa dan mulai dapat menerima kenyataan serta dapat menerapkan koping adaptif. Hudak \& Gallo (2009)

Menurut Bandura (1997) dalam Videbeck (2008) efikasi diri adalah keyakinan bahwa kemampuan dan upaya individu mempengaruhi peristiwa dalam hidup. Individu yang yakin bahwa tindakannya akan membuat suatu perbedaan cenderung untuk mengambil suatu tindakan. Individu yang memiliki efikasi diri yang tinggi menetapkan tujuan pribadi, memiliki motivasi diri melakukan koping secara efektif terhadap stress dan mendapatkan dukungan dari orang lain ketika ia membutuhkannya. Berdasarkan teori diatas menurut peneliti individu dengan keyakinan atau efikasi diri yang tinggi akan memiliki motivasi diri yang tinggi, mempunyai tujuan dalam hidupnya sehingga mampu mengatasi masalah yang dihadapi dengan menggunakan koping yang efektif.

\section{Hubungan Antara Dukungan Sosial Keluarga dengan Mekanisme KopingKlien Gagal Ginjal Kronik Yang Menjalani Hemodialisa}

Hasil penelitian menunjukkan ada hubungan yang signifikan antara dukungan sosial keluarga dengan mekanisme koping penderita Gagal Ginjal Kronik yang menjalani Hemodialisa. Hal ini diperkuat dengan tabel silang antara dukungan sosial keluarga dengan mekanisme koping dimana didapatkan hasil responden yang memiliki dukungan sosial keluarga baik sebagian besar memiliki mekanisme koping yang adaptif, sebaliknya responden yang memiliki dukungan sosial keluarga kurang baik sebagian besar memiliki mekanisme koping yang maladaptif.
Penelitian ini mendapatkan hasil masih adanya responden yang mendapatkan dukungan sosial keluarga baik namun memiliki mekanisme koping yang maladaptif, hal ini kemungkinan dikarenakan penyakit Gagal Ginjal Kronik merupakan penyakit kronis yang proses penyembuhannya lama dan tidak cukup hanya melakukan hemodialisa saja tetapi membutuhkan obat dan diet, sehingga penderita merasa bosan menghadapi penyakitnya sehingga timbul mekanisme koping maladaptif, faktor lain adalah ketergantungan dan kehilangan peran sehingga menimbulkan stress pada individu, hal ini didukung oleh penelitian Puspitasari (2014) dimana didapatkan hasil ada hubungan antara penampilan peran dengan stress pada klien gagal ginjal kronik yang menjalani Hemodialisa.

Responden dalam penelitian ini ada yang memiliki dukungan sosial keluarga kurang baik namun memiliki koping adaptif, kemungkinan bisa disebabkan karena faktor individu yang lain seperti faktor kesehatan fisik. Penderita sadar bahwa hanya dengan Hemodialisalah mereka dapat terus bertahan hidup. Kesehatan fisik dapat juga mempengaruhi cara individu berespon terhadap stress atau gangguan psikososial. Semakin sehat individu semakin baik kopingnya terhadap stress dan penyakit (Videbeck, 2008).

Dukungan keluarga merupakan salah satu faktor yang menyebabkan penderita Gagal Ginjal Kronik memiliki mekanisme koping yang adaptif. Pemberian dukungan berupa informasi tentang pentingnya hemodialisa, perhatian dan empati kepada penderita, mambantu dalam pemecahan masalah serta pemberian dukungan dalam bentuk biaya pengobatan, waktu tentu akan menyebabkan penderita merasa senang dan merasa dihargai saling memiliki dalam satu keluarga.Videbeck (2008) menyatakan bahwa keluarga merupakan sumber dukungan sosial yang dapat menjadi faktor kunci dalam penyembuhan klien. Walaupun keluarga tidak selalu memberikan dukungan positif namun mereka paling sering menjadi bagian penting dalam penyembuhan klien.

Menurut Friedmann (2013), keluarga dipandang sebagai suatu sistem, jika terjadi gangguan pada salah satu anggota keluarga dapat mempengaruhi seluruh sistem. 
Sebaliknya disfungsi keluarga dapat pula menjadi salah satu penyebab terjadinya gangguan pada anggota keluarga. Menurut Friedman dukungan keluarga merupakan suatu bentuk perhatian, dorongan yang didapatkan individu dari orang lain. Termasuk didalamnya mencakup bantuan langsung, seperti dalam bentuk uang, peralatan, waktu, modifikasi lingkungan maupun menolong pekerjaan. Hal ini didukung oleh penelitian Astutiningrum (2015) didapatkan hasil adanya hubungan dukungan sosial keluarga dengan mekanisme koping pada pasien gagal ginjal kronik yang menjalani Hemodialisa.

\section{SIMPULAN DAN SARAN \\ Simpulan}

Efikasi diri responden kategori tinggi dan rendah sama yaitu sebesar 50\%. Dukungan sosial keluarga yang diterima responden sebagian besar dalam kategori baik $(58.5 \%)$ dan $41.2 \%$ dalam kategori tidak baik. Mekanisme koping responden sebagian besar dalam kategori adaptif(76.5\%), mekanisme koping maladaptif sebanyak $23.5 \%$. Terdapat hubungan yang signifikan antara efikasi diri dengan mekanisme kopingdengan $\mathrm{p}$ value sebesar $0,039(\alpha=0,05)$. Terdapat hubungan yang signifikan antara dukungan sosial keluarga dengan mekanisme kopingdengan $\mathrm{p}$ value sebesar $0,004(\alpha=0,05)$.

\section{Saran}

Klien yang memiliki efikasi diri yang rendah diajnurkan untuk meningkatkan interaksi dengan penderita lain atau menganjurkan untuk bergabung dengan kelompok penderita Gagal Ginjal Kronik dengan Hemodialisa untuk saling berdiskusi dan bertukar pikiran agar mampu beradaptasi dengan kondisinya. Bagi klien yang memiliki dukungan sosial keluarga rendah dianjurkan untuk menjalin hubungan dan komunikasi yang baik dengan anggota keluarga dan menggunakan koping yang adaptif dengan lebih mendekatkan diri kepada sang pencipta.

Rumah Sakit hendaknya memfasilitasi pembentukan kelompok penderita gagal ginjal yang menderita hemodialisa sehingga menjadi tempat bertukar pikiran sesama penderita sehingga meningkatkan efikasi diridan dukungan sosial.

Perawat dapat meningkatkan Efikasi Diri klien melalui komunikasi terapeutik, meningkatkan dukungan sosial keluarga khususnya dukungan informasional dengan memberi informasi kepada keluarga tentang penyakit Gagal Ginjal Kronik dengan Hemodialisa dan meningkatkan mekanisme koping pasien melalui pemberian asuhan keperawatan yang komprehensif meliputi aspek biopsiko sosial kultural dan spiritual.

Keilmuan, hasil penelitian diharapkan dapat memberikan masukan bagi perkembangan ilmu pengetahuan, khususnya disiplin ilmu keperawatan mengenai pentingnya efikasi diri dan dukungan sosial terhadap mekanisme koping pasien yang menjalani hemodialisa.

Peneliti selanjutnya dapat melakukan penelitian lain dengan menggembangkan variabel yang lebih komprehensif meliputi faktor individual, faktor interpersonal dan faktor budaya.

\section{DAFTAR PUSTAKA}

Arinta, 2011, Gambaran Dukungan Keluarga pada Pasien GGK dalam Menjalani HD di RSUD Kota Semarang, Skripsi Tidak dipublikasikan, Semarang, FIKES Unimus

Asmarani, 2012, Koping Klien GGK Yang Menjalani Hemodialisa, Skripsi Tidak dipublikasikan, Semarang, FIKES Unimus

Astutingrum, 2015, Hubungan dukungan sosial keluarga dengan Mekanisme Koping Individu klien Gagal Ginjal yang Menjalani Hemodisias, Skripsi tidak dipublikasikan. Gombong, Stikes Muhammadiyah

Black, Hawk J.H, 2014, Keperawatan Medikal Bedah, Jakarta, Elsavier

Friedmann, M, 2013,Keperawatan keluarga: teori dan praktik. Ed 4. Alih bahasa: Ina Debora RL Editor: Yasmin Asih. Jakarta: EGC.

Hudak dan Galo, 2009. Keperawatan Kritis Pendekatan Holistik, Jakarta, Peberbit Buku Kedokteran EGC

Lestari T, 2015, Kumpulan Teori Untuk Kajian Pustaka Penelitian Kesehatan. Yogyakarta, Nuhamedika

Mutoharoh I, 2010, Faktor - Faktor Yang Berhubungan Dengan Mekanisme Koping Klien Gagal Ginjal Kronik Yang 
Menjalani Terapi Hemodialisis Di Rumah Sakit Umum Pusat (Rsup) FatmawatiTahun 2009. Jakarta PSIK Fakultas Kedokteran dan Ilmu Kesehatan UIN Jakarta, Skripsi tidak dipublikasikan

Nekada, 2012, Hubungan Antara Dukungan Keluarga Dengankepatuhan Pada Pasien Gagal Ginjal Kronik Dalam Menjalani Hemodialisis di RSUP Dr.Soeradji Tirtonegoro Klaten. Yogyakarta, Universitas Respati Yogyakarta, Skripsi Tidak Dipublikasikan

Puspitasari Arum, 2014, Hubungan Penampilan Peran dengan Stres Pada Pasien Gagal Ginjal Kronik di Unit Hemodialisa RSUD panembahan Senopati Bantul, Skripsi tidak dipublikasikan, Yogyakarta, PSIK Fikkes UMY

Rofiqoh S, dkk, 2013, Perbedaan Mekanisme Koping pada Pasien Gagal Ginjal Kronik Laki-laki dan Perempuan dalam Menjalani Hemodialisis di RSUD Kraton Kabupaten Pekalongan. Stikes Muhammadiyah Pekalongan

Septiady, Suhana, 2014, Hubungan antara Health Locus of Control dan Self Efficacy pada Pasien Gagal Ginjal Akut yang Menjalani Hemodialisa di Rumah Sakit Al-Islam Bandung. Bandung. Universitas Islam Bandung

Smeltzer and Bare. 2007. Buku ajar keperawatan medikal bedah, Brunner \& Suddart (Edisi8). Alih bahasa:Andry Hartono Kuncara, Elyna S. Laura Siahaan \& Agung Waluyo. Jakarta: Penerbit Buku Kedokteran, EGC.

Videback, 2008, Buku Ajar Keperawatan Jiwa, Alih Bahasa Komalasari R, Hany A, Editor Karyuni P.E, Jakarta EGC. 